\title{
Religiosity and Spiritual Well-Being of Senior High School Students of a Catholic College in the Philippines
}

\author{
Dennis V. Madrigal1*, Rosabella P. Erillo ${ }^{2}$ and Enrique G. Oracion ${ }^{3}$ \\ ${ }^{1}$ University of Negros Occidental-Recoletos \\ ${ }^{2}$ Philippine Association of Catholic Religious Educators \\ ${ }^{3}$ Silliman University \\ *dennis_madrigal@yahoo.com
}

\section{Abstract}

This study examined the religiosity and spiritual well-being of Catholic senior high school students of a rural Catholic school. Using the descriptive-comparative and correlational research design, data collection involved the survey questionnaires and hypotheses-testing used the Mann Whitney U test, Kruskal-Wallis, and Pearson r. In general, the students demonstrated a very high extent of religiosity, but they significantly differ when compared by grade level, church involvement, mass attendance, and Catholic identity. They had moderate spiritual well-being, but a significant difference was noted between males and females. Nevertheless, a significant relationship exists between religiosity and spiritual wellbeing, which suggests that the more the students observe Catholic teachings and practices, the more they mature in God's personal experience and achieve a sense of satisfaction and purpose in life. This study provides baseline data for developing the religious education curriculum and enhancing the campus ministry programs and activities of the said school.

Keywords: religiosity, spiritual well-being, religious well-being, existential well-being, senior high school students, descriptive-correlational, Catholic school, Philippines

\subsection{Introduction}

Being a predominantly Catholic country, religious affiliation to Catholicism in the Philippines still enjoys a large majority at $79.5 \%$ in the 2015 census (Philippine Statistics Authority, 2015). However, the online poll conducted by Social Weather Station (SWS) in December 2017 showed that only $75 \%$ of Filipino Catholics considered religion as very important. Also, the weekly church attendance among Catholics dropped to only $41 \%$, a significant decline from 64 percent in 1991 (SWS, 2018). Cornelio (2018) argued that the drop has not necessarily caused any alarm on the part of religious leaders because the statistics still translates into millions of attendees who fill the pews in their respective parishes. But surprisingly, it has also been observed that young Filipino Catholics seem to be losing their faith because 
they do not attend church services and understand their faith (Cornelio \& Sapitula, 2014). Despite their being unchurched, young Filipino Catholics are very much engaged in praying, Bible reading, faith activities, and charitable works in their respective school or community (Cornelio, 2016). Experts noted that many young Catholics are attracted to common and highly experiential modes of spirituality in Christian churches (Macasaet, 2009) and practiced varied religious typologies (Herzog, 2014). Cornelio (2016) described this phenomenon that young Catholics undergo as a paradigm shift on how they view and express religion. The decline in religious socialization among young Catholics (Asiones, 2018) signifies their deepest search for a more personal and experiential relationship with God (Lituañas, 2007). Though it is not a departure from the Church, but it clearly reveals a search for meaning as they engage in religious activities. In fact, the recent 6th Philippine Conference for the New Evangelization (PCNE) in Manila recognized the restlessness of young Filipino Catholics as they look for a supportive Church that can accompany them and enrich and strengthen their faith and spiritual life (Lucenion, 2019).

Recently, the "spiritual but not religious" (SBNR) phenomenon has been on the rise, attracting so many young people (Herzog, 2014; Debien \& Calderwood, 2016; Reese, 2017). Adherents simply express their desire to connect with the divine without being affiliated to any religion-a practice spirituality outside the context of institutional religion (Debien \& Calderwood, 2016; Barna Group, 2017). Maramba (2013) also observed that this phenomenon is a current trend among young Filipinos, which may present a problem to older people and a concern for the Church. Many people prefer to be called "spiritual" rather than "religious" due to the crisis in institutional religion. Findings of American Surveys support that spirituality does not go hand-in-hand with religiosity as many young people who claimed to be spiritual do not participate in religious practices (Lippman \& Mclntosh, 2010). However, Martin (2012) thinks that it is not easy or healthy to separate spirituality from religion. Both are essential in one's relationship with God and complementary. "Religion without spirituality becomes a dry list of dogmatic statements divorced from the life of the spirit... Spirituality without religion can be a selfcentered complacency divorced from the wisdom of a community" (p. 5).

Religiosity is usually recognized with the firm or formally structured religious organizations that usually are perceived to restrict or prevent human potential (Hill \& Hood, 1999). It is often observed as overlaying with certain aspects of spirituality, such as belief in divinity, but also encompasses making the specific practices of tending services or recognizing with the beliefs of a specific religion or religious group (Kim \& Esquivel, 2011). On the other hand, spirituality seems to be the preferred term to define the individual experience and is related to such things as personal transcendence, supra-conscious sensitivity, and meaningfulness (Spilka \& McIntosh, 1996). It can be encountered and communicated in multiple ways, such as being conscious of one's soul's sacredness, a relationship to a unity of life that surpasses oneself and to a divine Creator and/or being in a spiritual sphere such as angels (Kim \& Esquivel 2011).

The question now is, does SBNR phenomenon have become more prevalent among young Filipino Catholics? Is Catholic education still relevant and responsive in fostering students' holistic development (Barrett, 2016)? Inherent to its vision-mission, students' integral formation is supposedly at the heart of teaching and learning in 
Catholic schools (Shimabukuro, 2013). Grounded in Christian spirituality, the religious education in Catholic schools must be relevant, cognitively challenging, and interesting (Rymarz, 1999) as cited in Hatchman (2013) to respond to diverse contemporary learners' spiritual and religious needs.

With the literature review, the researchers were able to understand the necessity in looking at religiosity and spiritual well-being of the senior high school as a basis later on in crafting curriculum design, capacitating faculty, and improving activities and programs in rural Catholic College.

\section{Framework of the Study}

The paper theorized that religiosity and spiritual well-being are related (Lun \& Bond, 2013) and interconnected (Hill \& Pargament, 2003). Individual religious beliefs, observances, and involvement are closely linked with a distinct sense of transcendence and satisfaction with life or purpose (Yoon \& Lee, 2004; Kim-Prieto \& Miller, 2018). Religious beliefs and practices of particular religious group nurture and channel individual's sense of spirituality (Davison \& Jhangri, 2010); positively contribute to one's spiritual well-being or life's satisfaction (Koenig \& Larson, 2001; AbuRaiya, Pargament, Krause, \& Ironson, 2015; Krause, 2015; Mak, Han, You, Jin, \& Bond, 2011); and enhance resilience (Legada, Madrigal, \& Maravilla, 2020).

Religiosity. Religiosity is defined as a person's choices, emotions, beliefs, and behaviors that refer to an existing religion. It signifies the whole of cultural symbol-systems that answer to difficulties of meaning and possibility by relating to a surpassing reality that impacts everyday life; however, it cannot be directly controlled (Stolz,
2009). While religiosity is an individual, religion is a cultural phenomenon. According to Cardwell (1980) as cited in Holdcroft (2006), there are four dimensions of religiosity - cognitive, cultic, creedal, and devotional. The cognitive is involved with an individual's knowledge about religion (religious knowledge); the cultic refers to the individual's religious practices (ritualistic behavior); the creedal dimension involves personal belief; the devotional refers to a person's feelings and experiences in religion. Hence, "religious" people refer to people rooted in religion through membership in a church or sect whose beliefs, rules, traditions, rituals, and practices they adhere to and fervently or faithfully follow. As a result, religious people tend to institutionalize or maintain certain permanence in their beliefs and worship (Maramba, 2013).

Spirituality and spiritual well-being. Closely related to religiosity is spirituality, which touches on the "meaning and purpose in life, a search for wholeness and a relationship with a transcendent being" (Hage, 2006). Mansukhani and Resurreccion (2009) made use of the definition of spirituality by Zinnbauer et al. (1997), which states that spirituality is a bond with and faith in a Higher Power as well as the combination of values and beliefs with behavior in everyday life. The peculiar qualities of a relationship with a Higher Power are given importance and less on organizational or institutional beliefs and practices correlated with religiousness. Davison and Jhangri (2010) view spirituality as distinguished from religion, which comprises institutionally authorized beliefs and activities of a particular faith group and can help in nurturing and channeling expression of spirituality. Conversely, spirituality is perceived as "more basic" than religiosity and relates to transcendent values and the ways people discover purpose in life 
(Legada, Madrigal \& Maravilla, 2020). It may or may not include a belief in a higher being or organized religion.

With the above complex judgments, some people recognize themselves as "spiritual and religious", while others define themselves as "spiritual but not religious" (Mansukhani \& Resurreccion, 2009).

Speaking of spirituality, one essential and closely related companion to its concept is spiritual well-being (Paloutzian, Bufford \& Wildman, 2012). Spiritual well-being (SWB) refers to the subjective state of well-being, which measures the perceived spiritual quality of life in terms of religious sense and existential sense (Paloutzian \& Ellison, 1991). SWB is layman's term in which people describe "their relationship with God or what they understand as their spiritual well-being or their sense of satisfaction with life or purpose in life" (Paloutzian \& Ellison, 1991). On the other hand, Fisher (2011) describes spiritual well-being as the fundamental dimension of people's overall health, permeating and integrating all other dimensions of health (i.e., the physical, mental, emotional, social, and vocational).

Religiosity and spirituality and young Catholics. The study of Agoncillo (2015) on the religiosity of the Catholic youth in a developing country like the Philippines pointed that in terms of doctrine, the Filipino youth have average knowledge of Catholicism and articulate their views to a moderate extent only. In terms of morals, the respondents held beliefs that are moderately consistent with what the Catholic exercises. In terms of practices, they go to mass at least once a week, pray the rosary constantly, and frequently visit the Blessed Sacrament. Going to confession is done less frequently about a few times a year, while personal prayer is done several times a day. This study unveiled that gender, age, occupation, the religion of parents, socioeconomic status, and father's educational attainment are notable predictors of religiosity. Agoncillo (2015) further affirmed that religiosity as part of the youth experience is reliant on contextual factors such as socioeconomic status, family, school, community, Church, and church-based organizations, while, religiosity as a protector factor is an origin of comfort for the youth and promotes specific values, beliefs, and culture.

Relationship between religiosity and spiritual well-being. The role of religious beliefs and observances has a positive effect on an individual's well-being and life satisfaction despite life's setbacks, negative circumstances, or uncertainties (Abu-Raiya et al., 2015; Krause, 2015; Koenig \& Larson, 2001). Having strong faith convictions and religious involvement may decrease cognitive dissonance (Kitchens \& Phillips, 2018), maintain positive appraisal of one's life (Vishkin et al., 2016; Ramsay, Tong, Chowdhury, \& Ho, 2019), and strengthen the level of well-being (Galen \& Kloet, 2011). In addition, faithful adherence to Church teachings and practices, membership in church organization, and participation in the mass contributed to higher spiritual well-being (Oracion \& Madrigal, 2019).

In addition, Oracion and Madrigal (2019) confirmed that spiritual well-being is higher among religious groups, and significant differences are present in the spiritual well-being of Catholic high school students when they are grouped according to age and sex. In addition, the study discovered that orthodox Catholics demonstrate higher spiritual well-being and its two-fold componentsreligious and existential well-being - compared to 
creative and cultural Catholics. Results reveal that Orthodox Catholics demonstrated a more positive evaluation of life and a sense of life's satisfaction and purpose. Cornelio (2018) considers being orthodox and creative Catholics as emerging typologies of Catholic identity. The former puts premium adherence to traditional beliefs of the Catholic Church as handed down by my parents, who are devout Catholics. The latter are more selective on what they believe and practice as Catholics and more open to other religions (Cornelio, 2018; Oracion \& Madrigal, 2019).

The foregoing literature affirms that relating to God or other higher powers constitutes a basic human need expressed through some forms of religiosity and spirituality. Religiosity and spirituality are overlapping domains of human activity that afford human beings the experience of transcendence, satisfaction, and purpose. However, orthopraxis or right-doing is essential so that young Catholics may not be enticed by the current trends of deinstitutionalization and individualism, which discredit the religious beliefs and rituals of the institutional Church and privatize faith and experience of God. The most prevalent expressions include the "spiritual but not religious" (believe in God but never adhere to religious practices of the Church) and "love Jesus but not the Church" (Catholics but dechurched) (Barna Group, 2017). In this context, the literature offers the theoretical and conceptual perspectives to the investigation of the said phenomenon among young people so that the Church, Catholic schools - religious education and campus ministry programs, and family can better guide and assist the holistic religious and spiritual development of the students entrusted to their care.

\subsection{Methodology}

A descriptive-comparative and correlational research design were used to describe the extent of religiosity and degree of the spiritual wellbeing of 250 Catholic senior high school students of a rural Catholic school in the Philippines identified using a stratified random sampling method. A combination of a researcher-made and standardized questionnaire was used to gather the data and assess the extent of religiosity and degree of the spiritual well-being of Catholic senior high school students. For the spiritual well-being, the researcher used with permission the scale made by Paloutzian and Ellison (1991) available online by subscription. The spiritual well-being scale provides the indicator of the perceived spiritual quality of life of individuals in terms of their religious and existential well-being. The questionnaire is a paper-pencil self-administered instrument that consists of 20 items, and each of the subscales has ten items to assess the religious and existential well-being. The descriptive, comparative, and correlational analyses were utilized to analyze data using the appropriate statistical tools. Mean, Mann Whitney $U$ test, Kruskal-Wallis, and Pearson $r$ were employed for the statistical treatment of the data.

Prior to the conduct of the study, the parental assent from parents was secured to ensure the voluntary participation of senior high school students in the study. Also, the collected data were appropriately stored, protected, and deposed to safeguard the confidentiality of data and anonymity of the respondents. In addition, the researchers complied with the school Ethics Committee for the Ethical Standards in the conduct of the study. 


\subsection{Results and Discussion}

Extent of Catholic religiosity. Table 1 presents the extent of religiosity of Catholic senior high school students. The extent of Catholic religiosity as a whole $(M=4.29, S D=0.36)$ was "very high extent" with the doctrinal aspect as the highest $(M=4.79$, $S D=0.34)$ and practices as the lowest $(M=3.86$, $\mathrm{SD}=0.51$ ). The results indicate that students always observe the religious doctrines and practices of the Catholic faith.

In terms of doctrinal aspect, students who are male $(M=4.82, S D=0.25)$, Grade $12(M=4.80$, $\mathrm{SD}=0.26$ ), members of religious organizations $(\mathrm{M}=4.80, \mathrm{SD}=0.27)$, involved in Church ministry $(\mathrm{M}=4.88$, $S D=0.16)$, attended mass, not every Sunday $(M=4.80, \quad S D=0.27)$, and orthodox Catholics $(M=4.83, S D=0.40)$ rated themselves higher in Catholic beliefs compared to other respondents. Regarding the aspect of practices, respondents who are female $(M=3.89, S D=0.50)$, Grade $12(M=3.93, S D=0.53)$, members of religious organizations $(M=4.00, S D=0.46)$, involved in Church ministry $(M=4.01, S D=0.39)$, attended mass every Sunday $(M=3.96, S D=0.49)$, and orthodox Catholics ( $M=4.01, S D=0.48$ ) demonstrated higher rating in Catholic practices when compared to their counterparts.

Overall, students who are female $(M=4.29$, $\mathrm{SD}=0.38)$ grade $12(\mathrm{M}=4.33, \mathrm{SD}=0.35)$, members of religious organizations $(M=4.37, S D=0.29)$, involved in Church ministry $(M=4.41, S D=0.24)$, attended mass every Sunday $(M=4.34, S D=0.40)$, and orthodox Catholics ( $M=4.38, S D=0.38)$, and creative $(M=4.24, S D=0.31$ showed a very great extent of Catholic religiosity.
The very high extent of Catholic religiosity signifies that the Catholic senior high school students always exhibited their Catholic beliefs and practices. The high ratings were shown by those involved in the Church, members in religious organizations, and orthodox Catholics. The low ratings were evident from those who never attended mass, were creative and cultural Catholics, and are Grade 11 students. The findings of the study affirmed the results of the survey conducted by Lippman and McIntosh (2010) that young adults believed in God, considered the importance of God in their lives, and found religion to be important in life. Likewise, the results further validated the high religiosity of Filipino Catholics, especially the young people claimed by the studies of Cornelio (2016).

Moreover, the findings were also supported by previous studies that female were more religious, found more importance on religion, and committed to religious beliefs compared to male students as indicated in the National Study of College Students' Search for Meaning and Purpose in Life 2000-2003 (Lippman \& Mclntosh, 2010; Mayhew \& Bryant, 2013; Rich, 2012; Agoncillo, 2015).

Relative to grade levels, the findings of the study corroborated previous studies on the growing importance of religion among adolescents, indicating growth in appreciation of religious beliefs and practices as students progress in terms of grade levels. Religion has gradually become more important in the life of adolescents in recent years. Lippman and Mclntosh (2010) observed that religion is more important among 12th-grade female adolescents than male adolescents. 
Table 1. The Extent of Religiosity of Catholic Senior High School Students

\begin{tabular}{|c|c|c|c|c|c|c|c|c|c|}
\hline \multirow{2}{*}{ Variable } & \multicolumn{3}{|c|}{ Doctrinal } & \multicolumn{3}{|c|}{ Practices } & \multicolumn{3}{|c|}{ Catholic Religiosity } \\
\hline & $\mathbf{M}$ & SD & Int & M & SD & Int & $\mathbf{M}$ & SD & Int \\
\hline \multicolumn{10}{|l|}{ Sex } \\
\hline Male & 4.82 & 0.25 & VHE & 3.82 & 0.52 & $\mathrm{HE}$ & 4.27 & 0.33 & VHE \\
\hline Female & 4.78 & 0.39 & VHE & 3.89 & 0.50 & $\mathrm{HE}$ & 4.29 & 0.38 & VHE \\
\hline Grade Level & & & & & & $\mathrm{HE}$ & & & VHE \\
\hline Grade 11 & 4.78 & 0.40 & VHE & 3.80 & 0.48 & $\mathrm{HE}$ & 4.24 & 0.37 & VHE \\
\hline Grade 12 & 4.80 & 0.26 & VHE & 3.93 & 0.53 & $\mathrm{HE}$ & 4.33 & 0.35 & VHE \\
\hline \multicolumn{10}{|c|}{ Religious Org. Membership } \\
\hline Yes & 4.80 & 0.27 & VHE & 4.00 & 0.46 & $\mathrm{HE}$ & 4.37 & 0.29 & VHE \\
\hline No & 4.79 & 0.35 & VHE & 3.84 & 0.51 & $\mathrm{HE}$ & 4.27 & 0.37 & VHE \\
\hline \multicolumn{10}{|c|}{ Church Ministry Involvement } \\
\hline Yes & 4.88 & 0.16 & VHE & 4.01 & 0.39 & $\mathrm{HE}$ & 4.41 & 0.24 & VHE \\
\hline No & 4.78 & 0.36 & VHE & 3.83 & 0.52 & $\mathrm{HE}$ & 4.26 & 0.38 & VHE \\
\hline \multicolumn{10}{|l|}{ Mass Attendance } \\
\hline Every Sunday & 4.79 & 0.44 & VHE & 3.96 & 0.49 & $\mathrm{HE}$ & 4.34 & 0.40 & VHE \\
\hline Not every Sunday & 4.80 & 0.27 & VHE & 3.82 & 0.50 & $\mathrm{HE}$ & 4.27 & 0.33 & VHE \\
\hline Never & 4.25 & 0.21 & VHE & 3.00 & 0.59 & ME & 3.57 & 0.22 & $\mathrm{HE}$ \\
\hline \multicolumn{10}{|l|}{ Catholic Identity } \\
\hline Orthodox & 4.83 & 0.40 & VHE & 4.01 & 0.48 & $\mathrm{HE}$ & 4.38 & 0.38 & VHE \\
\hline Creative & 4.77 & 0.27 & VHE & 3.80 & 0.47 & $\mathrm{HE}$ & 4.24 & 0.31 & VHE \\
\hline Cultural & 4.71 & 0.40 & VHE & 3.56 & 0.68 & $\mathrm{HE}$ & 4.08 & 0.45 & $\mathrm{HE}$ \\
\hline As a Whole & 4.79 & 0.34 & VHE & 3.86 & 0.51 & $\mathrm{HE}$ & 4.29 & 0.36 & VHE \\
\hline
\end{tabular}

Note: VHE=Very High Extent, $H E=$ High Extent, ME=Moderate Extent

As regards to membership in religious organizations and involvement in Church ministry, the studies conducted by Madrigal (2016) on the knowledge and practices of high school students on the Holy Eucharist and Madrigal and Oracion (2018) on religiosity and spiritual well-being of students in a Catholic university reinforced the findings of the current study. Indeed, membership in religious organizations and involvement in whatever ministries in the Church can have a positive influence on one's religiosity and spirituality. Likewise, Hill and Hood (1999) reported that religious engagement is a positive and enlightening experience.

Furthermore, the result which indicated that orthodox Catholics were more religious compared to creative and cultural Catholics was confirmed by a study conducted by Oracion and Madrigal (2019) 
which also found that young Catholics in a Catholic university are still orthodox and their conservative adherence to Catholic beliefs and practices have a correlation in their Catholic religiosity; however, the results noted a growing percentage in terms of creative Catholics in a Catholic university. Meanwhile, Cornelio (2016) stated that being a creative Catholic is not necessarily a formal detachment from the Catholic religion. For many young Filipinos, it is about experiencing God and being able to express faith in practical ways; they become critical of their religion.

Finally, the very great extent of Catholic religiosity of senior high school students affirmed a similar study conducted by Madrigal and Oracion (2018) among Catholic college students in a Catholic university. The findings that Catholic religiosity tends more to be doctrinal and the current study validated the link between Catholic religiosity with membership in a religious organization, involvement in Church ministry, and regular attendance in mass. Meaning to say, Catholic religiosity among young Catholics is more identified with believing than doing in some sense. However, young people's sense of belongingness and involvement in the organization and ministry of the Church has influenced or shaped their religiosity.

Degree of spiritual well-being. Table 2 presents the degree of the spiritual well-being of Catholic senior high school students. In terms of religious well-being, the results reveal that students demonstrated a positive view of their relationship with $\operatorname{God}(M=52.21, S D=6.48)$. Students who are female $(M=53.42, S D=5.57)$, Grade $12(M=52.36$, $\mathrm{SD}=6.22)$, members of religious organizations $(M=52.45, S D=5.57)$, involving in Church ministry $(M=52.95, S D=5.59)$, attended mass every Sunday $(M=52.53, \quad S D=6.45)$, and orthodox Catholics
$(M=53.00, S D=6.32)$ showed higher religious wellbeing compared to other respondents.

Regarding their existential well-being, the findings show that students demonstrated a moderate level of life satisfaction and purpose. Students who are female $(M=46.37, S D=5.92)$, Grade $11(M=46.02, \quad S D=6.39)$, non-members of religious organizations $(M=46.00, S D=6.18)$, involved in Church ministry $(M=47.51, S D=6.41)$, attended mass every Sunday $(M=46.15, S D=6.24)$, and orthodox Catholics ( $M=46.95, \quad S D=6.08)$ displayed higher existential well-being compared to their peers.

As a whole, students reflected moderate spiritual well-being $(M=98.13, S D=11.35)$ with religious well-being $(M=52.21, S D=6.48)$ and existential well-being $(M=45.92, \quad S D=6.23)$ as the highest and lowest aspects, respectively. Students who had church ministry involvement demonstrate high spiritual well-being ( $M=100.46$, $S D=11.02)$. On the other hand, students who are female $(M=99.79, S D=9.88)$, Grade $12(M=98.16$, $\mathrm{SD}=10.96)$, non-members of religious organization $(M=98.17, S D=11.47)$, attending mass every Sunday $(M=98.68, S D=11.31)$, and orthodox Catholics $(M=99.95, S D=11.02)$ displayed a relatively higher mean score compared to other students in terms of spiritual well-being.

The findings of the study indicate that Catholic senior high school students exhibited average spiritual well-being. However, their positive relationship with God (religious) did not correspond to their sense of life satisfaction and purpose (existential). In the light of Fowler's spiritual development theory (Andrade, 2014), it posited that adolescents at the syntheticconventional level may believe but are not critical at what they believe and practice because of their strong sense of identity with the group. 
Table 2. Degree of Spiritual Well-being of Catholic Senior High School Students

\begin{tabular}{|c|c|c|c|c|c|c|c|c|c|}
\hline \multirow{2}{*}{ Variable } & \multicolumn{3}{|c|}{ Religious Well-being } & \multicolumn{3}{|c|}{ Existential Well-being } & \multicolumn{3}{|c|}{ Spiritual Well-being } \\
\hline & M & SD & Int & M & SD & Int & M & SD & Int \\
\hline \multicolumn{10}{|l|}{ Sex } \\
\hline Male & 50.30 & 7.31 & PVORG & 45.19 & 6.63 & MLLSP & 95.48 & 12.92 & MSWB \\
\hline Female & 53.42 & 5.57 & PVORG & 46.37 & 5.92 & MLLSP & 99.79 & 9.88 & MSWB \\
\hline \multicolumn{10}{|l|}{ Grade Level } \\
\hline Grade 11 & 52.06 & 6.72 & PVORG & 46.02 & 6.39 & MLLSP & 98.08 & 11.73 & MSWB \\
\hline Grade 12 & 52.36 & 6.22 & PVORG & 45.80 & 6.06 & MLLSP & 98.16 & 10.96 & MSWB \\
\hline \multicolumn{10}{|c|}{ Religious Org. Membership } \\
\hline Yes & 52.45 & 5.57 & PVORG & 45.40 & 6.47 & MLLSP & 97.85 & 10.67 & MSWB \\
\hline No & 52.17 & 6.64 & PVORG & 46.00 & 6.18 & MLLSP & 98.17 & 11.47 & MSWB \\
\hline \multicolumn{10}{|c|}{ Church Ministry Involvement } \\
\hline Yes & 52.95 & 5.96 & PVORG & 47.51 & 6.41 & MLLSP & 100.46 & 11.02 & HSWB \\
\hline No & 52.08 & 6.56 & PVORG & 45.61 & 6.15 & MLLSP & 97.69 & 11.36 & MSWB \\
\hline \multicolumn{10}{|l|}{ Mass Attendance } \\
\hline Every Sunday & 52.53 & 6.45 & PVORG & 46.15 & 6.24 & MLLSP & 98.68 & 11.31 & MSWB \\
\hline Not every Sunday & 52.06 & 6.52 & PVORG & 45.87 & 6.15 & MLLSP & 97.93 & 11.33 & MSWB \\
\hline Never & 51.00 & 4.24 & PVORG & 39.00 & 11.31 & MLLSP & 90.00 & 15.56 & MSWB \\
\hline \multicolumn{10}{|l|}{ Catholic Identity } \\
\hline Orthodox & 53.00 & 6.32 & PVORG & 46.95 & 6.08 & MLLSP & 99.95 & 11.02 & MSWB \\
\hline Creative & 51.75 & 6.86 & PVORG & 45.62 & 6.03 & MLLSP & 97.36 & 11.59 & MSWB \\
\hline Cultural & 51.35 & 4.17 & PVORG & 42.75 & 7.23 & MLLSP & 94.10 & 10.27 & MSWB \\
\hline As a Whole $(n=250)$ & 52.21 & 6.48 & PVORG & 45.92 & 6.23 & MLLSP & 98.13 & 11.35 & MSWB \\
\hline
\end{tabular}

Note: $P V O R G=$ Positive view of one's relationship with God, MLLSP=Moderate level of life satisfaction and purpose, $M S W B=$ Moderate spiritual well-being, $H S W B=H i g h$ spiritual well-being

Meaning to say, they may believe and practice their Catholic faith out of fear of being discriminated by authority or their peers without having experienced the connection of that faith in their lives. Though Filipino youth's spirituality is highly associated with the belief in God (National Social Science Council, 2003), young people do not necessarily express it through their religion (Baring,
Lee, Maria \& Lui, 2016).

As regards the variable sex, both male and female Catholic senior high school students registered a positive view of one's relationship with God, and both are experiencing a moderate level of life satisfaction and purpose. This resulted in moderate spiritual well-being. However, female students got a higher rating than male students. 
The findings confirmed Bryant's (2007) study on spirituality and the effect of college on students' spirituality, which revealed that women were found to have higher spirituality scores. Buchko's (2004) study on religious beliefs and practices of college women compared to college men explained that women would sense more of God's activity and presence in day-to-day life and reported more feelings of worship reverence than men. The result further reinforced the study conducted by Madrigal and Oracion (2018) that women are more religious and spiritual compared to men.

Concerning the variables of membership in religious organizations, church involvement, and attendance in mass, the findings of the study corroborated the results of the similar study conducted by Madrigal and Oracion (2018) that students who had membership in religious organizations, involved in the ministry of the Church, and attended mass every Sunday demonstrated a higher level of religiosity and spiritual well-being. Hill and Hood (1999) considered that forms of traditional religiousness such as prayer, church attendance, reading of sacred writings, and others are also spiritual if activated by an individual's search for the sacred. Likewise, the study conducted by Oracion and Madrigal (2019) on Catholic typology and spiritual well-being validated the result of the present study orthodox, wherein Catholics demonstrated a high level of religious and spiritual well-being.

Determinants of difference in Catholic religiosity. Using the Mann Whitney $U$ test, the findings show that no significant difference was found in the religiosity of Catholic senior high school students when they are grouped according to sex $[U=6936.0, p=0.384]$ and membership in the religious organization $[U=3700.0, p=0.232]$. However, significant differences are found in the religiosity of Catholic senior high school students when they are grouped according to grade level $[U=6672.0, p=0.046]$, involvement in Church ministry $[U=3128.5, p=0.017]$, and mass attendance $[U=5700.0, p=0.022]$. Hence, the null hypothesis that there is no significant difference in the extent of religiosity when Catholic senior high school students are grouped according to sex and membership in the religious organization was accepted. On the other hand, the null hypothesis that there is no significant difference in the extent of religiosity when Catholic senior high school students are grouped according to grade level, involvement in Church ministry, and Mass attendance was rejected.

The findings of the study indicate that Catholic senior high school students with high academic level, involvement in the ministry of the Church, and Mass attendance every Sunday significantly differed in terms of their Catholic religiosity compared to their counterparts. The absence of a significant difference in Catholic religiosity when respondents are grouped according to sex suggests that both male and female respondents did not vary in terms of their Catholic beliefs and practices. The results confirmed the findings of a similar study among Catholic college students conducted by Madrigal and Oracion (2018) and Oracion and Madrigal (2019) that significant differences in religiosity are found when respondents are grouped according to academic level, membership in a religious organization, and Mass attendance. The results may give the impression that religiosity and spiritual are capsuled to Mass attendance, devotions, and membership in a religious organization. However, it is important to 
understand that the aforementioned religious activities are essential pedagogical strategies that can aid students' religious and spiritual formation. In fact, Davison and Jhangri (2010) consider these religious practices to nurture and channel an individual's sense of spirituality. It may also bring positive effects to one's spiritual well-being or life satisfaction (Koenig \& Larson, 2001; Abu-Raiya et al., 2015; Krause, 2015; Mak et al., 2011).

On the other hand, Oracion and Madrigal (2019) theorized that it is possible that Catholic identity and religiosity. Meaning, the students must be more of orthodox Catholics, which may explain why they are more religious. Perhaps, the challenge for Catholic school's religious education and campus ministry programs is to strike a balance between the academic and evangelistic aspects of these religious activities so that their ultimate purpose - holistic spiritual and religious formation of students - may be achieved.

Using Kruskal Wallis, the results showed a significant difference in the religiosity of Catholic senior high school students when grouped according to Catholic identity $[\mathrm{H}(2)=18.935$, $\mathrm{p}=0.000]$. Post hoc tests revealed that Orthodox Catholics have significantly higher religiosity than creative and cultural Catholics. The findings reject the null hypothesis.

The results strongly indicate that adhering and observing all beliefs and practices of the Catholic Church strengthen or influence one's religiosity than simply being a cafeteria Catholics such as the case of creative and cultural Catholics who only choose what to believe and practice or assent and dissent in one or more doctrines and moral practices of the Catholic Church (Reese, 2017). The findings support Oracion and Madrigal (2019) that orthodox Catholics demonstrated higher religious and spiritual well-being than creative and cultural Catholics.

\section{Determinants of difference in spiritual well-}

being. Using Mann Whitney $U$ test, the results revealed that no significant difference was found in the spiritual well-being of Catholic senior high school students when they are grouped according to grade level $[U=7737.5, p=0.896]$, membership in a religious organization $[U=4021.0, p=0.669]$, church ministry involvement $[\mathrm{U}=3552.5, \mathrm{p}=0.175]$, and mass attendance $[U=6643.5, p=0.596]$. However, a significant difference exists in the spiritual well-being of Catholic senior high school students when they are grouped according to sex $[\mathrm{U}=6021.0 \mathrm{p}=0.012]$. Meaning to say, male and female students differed in the degree of their spiritual well-being but demonstrated congruent spiritual well-being in other demographic variables. Hence, the null hypothesis is accepted for grade level, membership in religious organizations church ministry involvement, and Mass attendance but rejected for sex.

The result further confirmed the findings of the study of Madrigal and Oracion (2018) on the significant difference in spiritual well-being and sex. However, it negated the difference in membership in religious organizations, involvement in Church ministry, and Mass attendance. On the other hand, the findings corroborated the difference in spiritual well-being and grade level and involvement in Church ministry with the study of Oracion and Madrigal (2019); meanwhile, it differed in terms of membership in religious organizations and Mass attendance.

Using Kruskal Wallis, the findings showed no significant difference in the spiritual well-being of Catholic senior high school students when 
grouped according to Catholic identity $[\mathrm{H}(2)$ $=5.058, p=0.080]$. Hence, the null hypothesis was accepted. The findings of the study suggest that when grouped according to their Catholic identity, respondents do not differ in terms of their personal experience of God and others. It further negated the findings of Oracion and Madrigal (2019) that orthodox Catholics significantly differed in their spiritual well-being compared to creative and cultural Catholics.

Relationship between religiosity and spiritual well-being. Pearson $r$ was used to determine the significant relationship between religiosity and well-being. The findings showed that there is a significant relationship between spiritual well-being and religiosity $[\mathrm{r}(248)=0.385$, $p=0.000]$. Hence, the null hypothesis was rejected. The results further confirmed the findings of the study conducted by Madrigal and Oracion (2018) that a significant relationship exists between religiosity and spiritual well-being. Meaning to say, religious beliefs and practices are closely linked with spiritual well-being. The more Catholic senior high school students adhere to and observe the Catholic beliefs and practices, the more they grow and mature in their personal experience of God and others.

Bufford (1984) confirmed this positive correlation between religious and spiritual wellbeing. The role of religious affiliation, religious knowledge church attendance, and personal devotions are significantly linked with spiritual well-being. Paloutzian and Ellison (1979) as cited in Ellison (1983), Altemeyer (2004) underscored that spiritual well-being constituted two overlapping dimensions-religious and existential well-being. The former refers to one's sense of well-being in relation to God (vertical dimension), and the latter is a sense of life purpose and life satisfaction (horizontal dimension). Meaning to say, growth in spiritual well-being connotes growth in one's relationship with God and an increase of life satisfaction and a sense of purpose.

\subsection{Conclusion}

The study disclosed that Catholic senior high school students had demonstrated religiosity to a very great extent but only moderately their spiritual well-being. They exhibited strong Catholic religious beliefs and practices while having an average positive relationship with God and a sense of life satisfaction and purpose as adolescent Catholics. Therefore, the study concluded that Catholic students highly exposed in a religious organization and its activities, involved in Church ministry, regularly attended masses, and fervently observed the teachings and practices of the Catholic faith had achieved growth and maturity in their personal experience of God, sense of life satisfaction, and purpose.

\section{Recommendations}

In view of the findings of the study, it is recommended that varied religious and spiritual activities in collaboration with the Campus ministry staff may be organized by teachers to enhance the development of religiosity and achievement of the spiritual well-being of their students. In particular, religion teachers may undertake more training and formation in the content, pedagogy, and spirituality to enhance their expertise and skills in teaching the Catholic faith and forming the minds, hearts, and souls of their students. Likewise, membership in religious organizations, involvement in the 
different ministries of the Church, Mass attendance at least every Sunday, and participation in school or parochial religious and spiritual activities may be strongly encouraged among senior high school students so that they may enhance their Catholic religiosity and spirituality. Moreover, this study will help in developing the Catholic College curriculum to enhance campus ministry programs and activities that will help the students develop their religiosity and spiritual well-being. Furthermore, the findings may guide future researchers to conduct related studies that will explore other variables not covered by the study or replicate the study to a larger sample and more schools in different contexts to validate or contest the findings of the study.

\section{References}

Abu-Raiya, H., Pargament, K. I., Krause, N., \& Ironson, G. (2015). Robust links between religious/spiritual struggles, psychological distress, and well-being in a national sample of American adults. American Journal of Orthopsychiatry, 85(6), 565.

Agoncillo, R.L. (2015). Understanding Catholic youth religiosity in a developing country. In the International Conference on Language, Education, Humanities, and Innovation (pp.127-134). Retrieved from https://icsai. org/procarch/1iclehi/1iclehi-47.pdf

Altemeyer, B. (2004). Perspectives: The decline of organized religion in western civilization. The International Journal for the Psychology of Religion, 14(2), 77-89.

Andrade, A. (2014). Using Fowler's faith development theory in student affairs practice. College Student Affairs Leadership, $1(2), 2$

Asiones, Noel. (2018). The National Filipino Catholic Youth study of 2014.Retrieved from https://www.researchgate.net/ publication/327745391_The_National_ Filipino_Catholic_Youth_Study_of_2014

Baring, R. V., Lee, R., Maria, M., \& Liu, Y. (2016). Configurations of student Spirituality/ Religiosity: evidence from a Philippine university. International Journal of Children's Spirituality, 21(3-4), 163-176.

Barna Group. (2017 April 6). Meet the "spiritual but not religious." Retrieved from http://www. barna.com/research/meet-spiritual-but-notreligious

Barrett, M. C. S. (2016). Dimensions of spirituality fostered through the PULSE Program for Service Learning. Journal of Catholic Education, 20(1), n1.

Bryant, A. N. (2007). Gender differences in spiritual development during the college years. Sex roles, 56(11-12), 835-846.

Buchko, K. J. (2004). Religious beliefs and practices of college women as compared to college men. Journal of College Student Development, 45(1), 89-98.

Bufford, R. K. (1984). Empirical Correlates of the Spiritual Well-Being and Spiritual Maturity Scales. 
Cornelio, J.S. (2016) Being Catholic in the Contemporary Philippines, Young people reinterpreting religion. London and New York: Routledge Taylor \& Francis Group.

Cornelio, J. S. (2018). Young people and the challenges of religious education in the Philippines. In M. Fabrizio (Ed.), Youth, the Catholic Church, and religions in Asia. Italy: Urbaniana University Press. Pp. 79-112.

Cornelio, J. S., \& Sapitula, M. J. (2014, November 20). Are we losing Faith? An invitation to the Sociology of Religion in the Philippines. Retrieved from https://socialstudiescorner. wordpress.com/2014/11/20/are-we-losingfaith-an-invitation-to-the-sociology-ofreligion-in-the-philippines/

Davison, S. N., \& Jhangri, G. S. (2010). Existential and religious dimensions of spirituality and their relationship with health-related quality of life in chronic kidney disease. Clinical Journal of the American Society of Nephrology, 5(11), 1969-1976.

Debien, N., \& Calderwood, K. (2016, August 08). 'Spiritual but not religious': What the census won't say about Australians' beliefs. ABC. Retrieved June 25, 2020, from https:// www.abc.net.au/radionational/programs/ religionandethicsreport/spiritual-butnot-religious-what-the-census-wontsay/7699694

Ellison, C. W. (1983). Spiritual well-being: Conceptualization and measurement. Journal of psychology and theology, 11(4), 330-338.
Ellison, C. W. \& Paloutzian, R. F. (2009).The spiritual well-being scale. Life Advance. Retrieved from https://www.lifeadvance.com/spiritual-wellbeing-scale.

Fisher, J. (2011). The four domains model: Connecting spirituality, health and wellbeing. Religions, 2(1), 17-28.

Galen, L. W., \& Kloet, J. D. (2011). Mental wellbeing in the religious and the non-religious: Evidence for a curvilinear relationship. Mental Health, Religion \& Culture, 14(7), 673689.

Hage, S. M. (2006). A closer look at the role of spirituality in psychology training programs. Professional Psychology: Research and Practice, 37(3), 303.

Hatchman, D. J. (2013). Family and school influences on the religious practice and spiritual lives of Catholic adolescents [Doctoral dissertation, Southern Cross University]. Southern Cross University. Retrieved from https://epubs.scu. edu.au/theses/371/

Herzog, P. S. (2014). Are emerging adults "spiritual but not religious"? Institute for Faith and Learning, (pp. 65-72). USA: Baylor University. Retrieved from www.baylor.edu//content/ services/document.php/224506.pdf

Hill, P. C., \& Hood, R. W. (Eds.). (1999). Measures of religiosity (pp. 119-58). Birmingham, AL: Religious Education Press.

Hill, P. C., \& Pargament, K. I. (2003). Advances in the conceptualization and measurement 
of religion and spirituality: Implications for physical and mental health research. American psychologist, 58(1), 64.

Holdcroft, B. B. (2006). What is religiosity. Catholic Education: A Journal of inquiry and practice, 10(1).

Kim, S., \& Esquivel, G. B. (2011, June 15). Adolescent spirituality and resilience: Theory, research, and educational practices. Psychology in the Schools, 48(7), 755-765. doi:10.1002/ pits.20582

Kim-Prieto, C., \& Miller, L. (2018). Intersection of religion and subjective well-being. Handbook of well-being. Salt Lake City, UT: DEF Publishers.

Kitchens, M. B., \& Phillips III, R. E. (2018). A curvilinear relationship between clear beliefs about God and self-concept clarity. Psychology of Religion and Spirituality.

Koenig, H. G., \& Larson, D. B. (2001). Religion and mental health: Evidence for an association. International Review of Psychiatry, 13(2), 6778.

Krause, N. (2015). Religious doubt, helping others, and psychological well-being. Journal of Religion and Health, 54(2), 745-758.

Legada, E. L., Madrigal, D. V., \& Maravilla, M. W. M. (2020). Spiritual Well-Being and Resiliency of the Diocesan Seminarians of Antique. Philippine Social Science Journal, 3(1), 53-69. Retrieved from https://philssj.org/index. php/main/article/view/124
Lippman, L. H., \& Mclntosh, H. (2010). The demographics of spirituality and religiosity among youth: International and US Patterns. Child Trends Research Brief, 2010-21.

Lituañas, C. R. A. (2007). An inquiry at the Millennial youth spiritual identity: Experiences of DLSU students. In DLSU arts Congress (pp. 1-12).

Lucenion, M. (2019, July 22). Young Catholics search for 'supportive' Church. Union of Catholic Asian News. Retrieved from https:// www.ucanews.com/news/young-catholicssearch-for-supportive-church/85694

Lun, V. M. C., \& Bond, M. H. (2013). Examining the relation of religion and spirituality to subjective well-being across national cultures. Psychology of Religion and Spirituality, 5(4), 304.

Macasaet, M. (2009). The spiritual journey of young Filipinos. In G. Leung (Ed.), The Y Factor: 2009 Yearbook on the Filipino Youth. Makati: Salesians Missions, 10-15.

Madrigal, D. V. (2016, August 3-5). Understanding and practices of the Sacrament of the Holy Eucharist. Paper presented at the 1st Recoletos Research Congress, University of San Jose-Recoletos, Cebu City, Philippines.

Madrigal, D. \& Oracion, E. (2018.). Religiosity and spiritual well-being of students in a Philippine Catholic University. Book of Abstracts of the 2018 PSS National Conference, (p. 37). Siquijor: Philippine Sociological Society. 
Mak, M. C. K., Han, Y. M. Y., You, J., Jin, M., \& Bond, M. H. (2011). Building life satisfaction through attachment to mother and beliefs about the world: Social axioms as mediators in two cultural groups. Mental Health, Religion \& Culture, 14(3), 223-239.

Mansukhani, R., \&Resurreccion, R. (2009). Spirituality and the development of positive character among Filipino adolescents. Philippine Journal of Psychology, 42(2).

Maramba, A. D. (2013, April 25). Spiritual but not religious. Inquirer.Net. Retrieved from https://opinion.inquirer.net/51425/spiritualbut-not-religious

Martin, J. (2012, November 16). Spiritual and religious: The benefits of being both. Thinking Faith: The online journal of the Jesuits in Britain. Retrieved from https://www. thinkingfaith.org/articles/20121116_1.htm

Mayhew, M. J., \& Bryant, A. N. (2013).Achievement or arrest? The influence of the collegiate religious and spiritual climate on students' worldview commitment. Research in Higher Education, 54(1), 63-84.

National Social Science Congress. (2003). The Filipino youth: Some findings from research. Quezon City: Technical Services and Information Section, Philippine Social Science Council.

Oracion, E., \& Madrigal, D. (2019). Catholic Identity and Spiritual Well-Being of Students in a Philippine Catholic University. Recoletos Multidisciplinary Research Journal, 7(2), 47-
60. https://doi.org/10.32871/rmrj1907.02.04

Paloutzian, R. F., Bufford, R. K., \& Wildman, A. J. (2012). Spiritual well-being scale: Mental and physical health relationships. Oxford textbook of spirituality in healthcare, 353-358.

Paloutzian, R. F., \& Ellison, C. W. (1991). Manual for the spiritual well-being scale. Nyack, NY: Life Advance.

Philippine Statistics Authority . (2015). 2015 Census of Population. Republic of the Philippines: Philippine Statistics Authority Retrieved from https://psa.gov.ph/statistics/census/2015census-of-population

Ramsay, J. E., Tong, E. M., Chowdhury, A., \& Ho, M. H. R. (2019). Teleological explanation and positive emotion serially mediate the effect of religion on well-being. Journal of personality, 87(3), 676-689.

Reese, T. (2017, October 3). More Catholic than the pope. Religion News Service. Retrieved from https://religionnews.com/2017/10/03/ more-catholic-than-the-pope/

Rich II, A. (2012). Gender and spirituality: Are women really more spiritual?. Liberty University Digital Commons. Retrieved from https:// digitalcommons.liberty.edu/honors/281

Shimabukuro, G. (2008). Toward a pedagogy grounded in Christian spirituality. Journal of Catholic Education, 11(4), 8.

Social Weather Stations (2018). Attendance at religious services among adults, Philippines, 1991-2017 [Table]. Fourth Quarter 2017 
Social Weather Survey: Minorities of Filipino adults attend religious services weekly since 2013; 75\% said religion is very important, 9\% somewhat important. Retrieved from https:// www.sws.org.ph/swsmain/artcldisppage/?a rtcsyscode $=$ ART -20180328121738

Spilka, B., \& Mclntosh, D. N. (1996, August). Religion and spirituality: The known and the unknown. In American Psychological Association annual conference, Toronto, Canada.

Stolz, J. (2009). Explaining religiosity: towards a unified theoretical model 1. The British journal of Sociology, 60(2), 345-376.

Vishkin, A., Bigman, Y. E., Porat, R., Solak, N., Halperin, E., \& Tamir, M. (2016). God rest our hearts: Religiosity and cognitive reappraisal. Emotion, 16(2), 252.

Yoon, D. P., \& Lee, E. K. O. (2004). Religiousness/ spirituality and subjective well-being among rural elderly Whites, African Americans, and Native Americans. Journal of Human Behavior in the Social Environment, 10(1), 191-211.

Zinnbauer, B. J., Pargament, K. I., Cole, B., Rye, M. S., Butter, E. M., Belavich, T. G., ... \& Kadar, J. L. (1997). Religion and spirituality: Unfuzzying the fuzzy. Journal for the scientific study of religion, 549-564. 